\title{
Energy efficiency of diet for periparturient dairy cows supplemented with free fatty acids or glucogenic additives
}

\author{
RENATA KLEBANIUK, GRZEGORZ KOCHMAN, EDYTA KOWALCZUK-VASILEV, \\ EUGENIUSZ R. GRELA, MACIEJ BĄKOWSKI, MAGDALENA OLCHA, FILOMENA DUNSTER
}

Institute of Animal Nutrition and Bromatology, University of Life Sciences in Lublin, Akademicka 13, 20-950 Lublin, Poland

Received 29.06.2016

Accepted 05.09.2016

Klebaniuk R., Kochman G., Kowalczuk-Vasilev E., Grela E. R., Bąkowski M., Olcha M., Dunster F. Energy efficiency of diet for periparturient dairy cows supplemented with free fatty acids or glucogenic additives

Summary

The aim of the study was to compare the efficiency of two energy preparations used at fixed doses, but for different lengths of time: 1) a loose mixture of propylene glycol and sodium propionate, and 2) a granular formulation of free fatty acids produced from palm oil and palm nut, non-degradable in the rumen.

A three-factorial experiment was carried out on 5 groups of Polish Black and White Holstein-Friesian cows (10 animals each) which were within the transition period. The aim of the experiment was to determine the effect of two energy preparations administered at a constant dose, but over different time periods, on the animals' performance, as well as on their milk yield and composition. The following treatment groups were formed: control group C, which received a standard diet; experimental groups G1 and G2, which received a dietary additive of a glucogenic preparation; and experimental groups F1 and F2, which received a free fatty acid preparation. The diet of the transition cows was supplemented with the full dose of the additives $(500 \mathrm{~g} /$ head/day) for 2 weeks before the expected calving and 3 or 6 weeks of lactation.

The present research confirmed the benefits of dietary inclusion of energy supplements for transition cows. Supplementation with both glucogenic and free fatty acid preparations reduced the negative energy balance in the cow's organism and improved milk production and composition. The milk yield, higher by ca. $10 \%$ for the cows fed diets with energy additives (relative to the control treatment), provides evidence of a substantial beneficial effect of supplemental dietary energy on the efficiency of cow milk production.

In the present study, the best basic milk composition was obtained in the cows receiving a dietary addition of the glucogenic preparation at a dose of $500 \mathrm{~g} / \mathrm{head} / \mathrm{day}$ until the end of the $6^{\text {th }}$ lactation week. The animals from this group also had the highest milk yield evaluated for 305 days. In order to improve the energy balance in high-yielding transition cows, it is recommended that dairy managers apply feed energy additives based on propylene glycol and sodium propionate.

Keywords: cows, milk, blood, urine, energy additives

High-producing dairy cows require an appropriate management system, good care, and a tailored nutritional program that provides well-balanced feed rations. High yielders, especially during the periparturient period, normally show a reduced feed intake with a concomitant increased demand for nutrients for milk synthesis. Thus, the incidence of metabolic disorders may greatly increase, and consequently, a decrease in milk production is noted. Deterioration in milk composition is also observed (4). Although a range of energy additives to ruminant diets has been extensively investigated $(7,48)$, an ongoing research focused on the negative energy balance of periparturi- ent dairy cows is required $(29,50)$. In this regard, much attention is given, among others, to the use of energy feed additives in dairy cow diets and to their impact on animal metabolism and performance, as well as on milk composition. Each of gluconeogenic precursors, such as glycerol (51), propylene glycol (28), sodium or calcium salts of propionate (30), has a different route for conversion to glucose. Depending on their type and administration period, energy supplements may contribute to reducing metabolic disturbances during the transition period. Propylene glycol may affect glucogenic action in different ways. A portion of this substance is metabolized in the rumen to lactic acid 
and propionic acid, which are converted to glucose by hepatocytes; the glycol portion which escapes rumen fermentation, is absorbed by the rumen wall or from the gastrointestinal tract and is converted to glucose by the liver (28).

In ruminants, propionate serves as an energy source and may also act independently as a metabolic mediator of nutritional status (14). Propionate is the primary glucogenic substrate in the dairy cow, and thus pathways for the use of this glucose precursor are stimulated in the dairy cow. Propionate is easily absorbed into blood in the rumen wall and transported to the liver, where it is converted into glucose via gluconeogenesis (47). The conversion of propionate to glucose depends on conversion to propionyl co-A and to succinyl co-A before entry into the citric acid cycle and subsequently into the gluconeogenic pathway by the activity of phosphoenol pyruvate carboxykinase (17). However, glucogenic agents may have detrimental influence on feed intake (39). On the other hand, a common practice today is to meet energy requirements for milk production, reproduction, and body condition restoration by the inclusion of fat in diets of lactating dairy cows. The fatty acid composition of rumen-inert fats include long-chain fatty acids (LCFAs), the most common being palmitic (C16:0), stearic (C18:0), oleic (C18:1), and linoleic (C18:2) acids. LCFAs are not just a source of energy, but are also bioactive compounds and have metabolically different functions in the cow (31). The presence and roles of C16:0 and C18:0 FA in dairy cow metabolism are quite different $(9,20)$. Palmitic acid is a fatty acid (FA) found in the greatest quantity in milk fat. Dietary sources of C16:0 generally increase milk fat yield and are used as an energy source for milk production and replenishing body weight lost during periods of negative energy balance. Stearic acid is the most abundant FA available to the dairy cow and is used to a greater extent for milk production and energy balance than C16:0. A series of studies reviewed by Loften et al. (31) suggest that feeding a combination of C16:0 and C18:0 may optimize their utilization for the milk production and overall performance of dairy cows. However, longer-term lactation studies are needed to better determine and evaluate lasting affects on milk FA composition and yield when only C16:0 or C18:0 is fed.

Such supplements can also have an effect on the level of biochemical indicators related to energy metabolism: e.g. glucose, beta-hydroxbutyric acid (BHBA), non-esterified fatty acids (NEFA), and cholesterol $(12,15,42)$. Moreover, energy supplements affect milk yield and composition. Given different modes of action of the two additives used as energy sources (a glucogenic one - energy available in the rumen, and a formulation of free fatty acid - a rumen-inert energy source), the aim of the present research was to evaluate the impact of different time periods of their administration to transition cows on the cows' performance as well as blood and urine parameters.

\section{Material and methods}

Experimental design and animal feeding management. The study included 50 Polish Black-and-White Holstein-Friesian dairy cows allocated into 5 treatment groups (10 animals each) with an average annual milk yield of 8725 liters and with $3.26 \%$ protein and $3.84 \%$ fat content. The cows were managed under a tie-stall housing system. The animals were placed in the experimental groups successively, during their drying-off onset, as assessed by the analogue method, taking into account their age, annual milk production in the previous lactation, and body weight. All the animals were fed in compliance with the IZ PIB-INRA (18) standards. The main ingredients of their basal diets were (nutritive value of $1 \mathrm{~kg} \mathrm{DM}$ ): maize silage ( $0.89 \mathrm{UFL}$ - feed unit for milk production, $52 \mathrm{~g}$ PDIN - protein truly digestible in the small intestine when $\mathrm{N}$ limits microbial protein synthesis, $69 \mathrm{~g}$ PDIE - protein truly digestible in the small intestine when energy limits microbial protein synthesis, 1.09 LFU - fill units for cows), grass haylage (0.78 UFL, $74 \mathrm{~g}$ PDIN, $69 \mathrm{~g}$ PDIE, $1.23 \mathrm{LFU})$, ensiled maize grain ( $0.67 \mathrm{UFL}, 39 \mathrm{~g}$ PDIN, 49 g PDIE), meadow hay (0.62 UFL, 56 g PDIN, $61 \mathrm{~g}$ PDIE, 1.18 LFU), and the basal concentrate (1.01 UFL, $175 \mathrm{~g}$ PDIN, $133 \mathrm{~g}$ PDIE). The main ingredients of their basal diets were given in a mix form (PMR) at a ratio of $35: 40: 5: 15: 5$ (DM basis), respectively, in the dry period, and at a ratio of $50: 20: 20: 2: 8$ during lactation. Additionally, all the cows with a daily milk yield over $18 \mathrm{~kg}$ received an appropriate amount of the experimental concentrate (MP).

The experimental factors were a loose glucogenic preparation (G) composed of propylene glycol (BASF) and sodium propionate (99\% purity, Pestell Minerals\&Ingredients, New Hamburg, Canada) $(50: 50)$ and a free fatty acid preparation (F; own composition) containing C 16:0, C 14:0, and C 18:0 fatty acids at a $98: 1: 1$ ratio and produced from palm oil and palm kernel as rumen-undegradable pellets. The diet of the transition cows was supplemented daily for 5 or 8 weeks (for 2 weeks before the expected calving and 3 or 6 weeks of lactation) with the full dose of the experimental additives (500 g per head) as a component of the experimental concentrate. The dose of the additives was based on the authors' previous experiments (22-24) and the available literature $(31,32,41)$.

Thus, for purposes of this experiment, 5 groups were formed: a control group $(\mathrm{C})$, which received a standard diet, and 4 experimental groups with a dietary additive of the glucogenic preparation (G1 and G2) or the free fatty acid preparation (F1 and F2) (Tab. 1). To ensure the total intake of

Tab. 1. Experiment design

\begin{tabular}{|c|c|c|}
\hline Group & $\begin{array}{c}\text { Dose of experimental additives } \\
{[\mathrm{g} / \text { head/day] }}\end{array}$ & $\begin{array}{c}\text { Duration of additive application } \\
\text { [weeks prior/post calving] }\end{array}$ \\
\hline C & - & - \\
G1 & 500 & $-2 /+3$ \\
G2 & 500 & $-2 /+6$ \\
F1 & 500 & $-2 /+3$ \\
F2 & 500 & $-2 /+6$ \\
\hline
\end{tabular}

Explanations: $\mathrm{G}$-glucogenic preparation (loose propylene glycol and sodium propionate at $50: 50$ ratio); $\mathrm{F}$ - free fatty acid preparation $(\mathrm{C} 16: 0, \mathrm{C} 14: 0$ and $\mathrm{C} 18: 0$ at $98: 1: 1$ ratio) 
Tab. 2. Composition of concentrates introduced into diet

\begin{tabular}{|c|c|c|c|c|}
\hline Component & \multicolumn{3}{|c|}{$\%$} & $\mathrm{MP}_{\mathrm{F}}$ \\
\hline Barley & 25.5 & 12 & 6 & 6 \\
\hline Wheat & 0 & 12 & 6 & 6 \\
\hline Maize & 0 & 21.5 & 10.75 & 10.75 \\
\hline Wheat bran & 30 & - & - & - \\
\hline Soybean meal (46\% CP) & 20 & 28 & 14 & 14 \\
\hline Rapeseed meal 00 (35\% CP) & 20 & 22 & 11 & 11 \\
\hline Soybean oil & 1 & 1 & 0.5 & 0.5 \\
\hline Mineral-vitamin mixture* & 2.5 & 2.5 & 1.25 & 1.25 \\
\hline Sodium carbonate & 1 & 1 & 0.5 & 0.5 \\
\hline Glucogenic preparation (G) & - & - & 50 & - \\
\hline Free fatty acid preparation (F) & - & - & - & 50 \\
\hline \multicolumn{5}{|l|}{ Nutritive value of $1 \mathrm{~kg} \mathrm{DM}{ }^{2}$} \\
\hline UFL & 1.01 & 1.14 & 1.63 & 1.70 \\
\hline PDIN, g & 175 & 194 & 155 & 157 \\
\hline PDIE, g & 133 & 156 & 189 & 171 \\
\hline
\end{tabular}

Explanations: M0 - basal concentrate; MP - experimental concentrate (given to cows with daily milk yield exceeding $18 \mathrm{~kg}$ ); $\mathrm{MP}_{\mathrm{G}}$ - experimental concentrate with glucogenic preparation; $\mathrm{MP}_{\mathrm{F}}$ - experimental concentrate with free fatty acid preparation; * content of each mineral component varied among dry and lactating cows; UFL $=$ Feed Unit for milk production; PDIN = protein truly digestible in the small intestine when $\mathrm{N}$ limits microbial protein synthesis; PDIE = protein truly digestible in the small intestine when energy limits microbial protein synthesis

the experimental supplements, the experimental concentrate was offered to animals individually, at the morning feeding, in two parts. The first part $(1 \mathrm{~kg})$ of the experimental concentrates, which included the additives $\left(\mathrm{MP}_{\mathrm{G}}\right.$ or $\left.\mathrm{MP}_{\mathrm{F}}\right)$ (Tab. 2), and the other part of the concentrate (MP), with no experimental supplements, were provided on a regular basis in order to meet standard animal nutritional requirements.

Experimental procedures, sampling, and analysis. The study evaluated the chemical composition and nutritive value of diet ingredients, the cows' body condition score and production efficiency, as well as milk composition. During the research ( 3 weeks prior to parturition and in the $2^{\text {nd }}$ and $14^{\text {th }}$ weeks after calving), the body condition score (BCS) of the experimental animals was assessed. The feeds were analyzed for the basal nutrient content according to methods approved by AOAC (2). The energy value of $1 \mathrm{~kg} \mathrm{GA}$, consisting of propylene glycol and Na-propionate mixed $1: 1$, was calculated as 2.0-2.5 UFL on the basis of the energy value (computed in $\mathrm{NE}_{\mathrm{L}}$ ) by Miyoshi et al. (35) for $1 \mathrm{~kg}$ propylene glycol and by Liu et al. (30) for Na-propionate, whereas the fatty acids preparation supplied 2.5-3.0 UFL of energy per $1 \mathrm{~kg}$ (data not shown).

Milk yield was recorded and milk samples for chemical analysis were collected at the end of the $2^{\text {nd }}, 6^{\text {th }}, 10^{\text {th }}$, and $14^{\text {th }}$ weeks of lactation. The fat content and protein content of the milk samples was determined using a Milko-Scan apparatus (Bentley Instruments Inc., Chaska, USA). For a better comparison of the milk energy yield, the milk energy value was calculated using an equation proposed by Tyrrell and Reid (49).

Blood and urine samples were taken from the cows three weeks prior to the planned delivery and in the $2^{\text {nd }}, 6^{\text {th }}, 10^{\text {th }}$, and $14^{\text {th }}$ weeks after calving. The samples were obtained from each cow in the morning after milking and before feeding. Blood was sampled from the external jugular vein into test tubes filled with heparin. Urine was sampled by means of disposable catheters into sterile containers.

After centrifugation of the blood in the laboratory, biochemical plasma parameters, such as glucose (GLU), total cholesterol (CHOL), triacylglycerols (TG), and HDL-chol fractions, were determined by colorimetric methods with Cormay monotests and a Helios Epsilon spectrophotometer. The lipoprotein fraction of low-density cholesterol (LDL) was calculated by Friedewald's formula (11): LDL ( $\mathrm{mmol} \mathrm{l}^{-1}$ ) $=$ total cholesterol $-\mathrm{HDL}-$ triglycerides/2.2. The enzymatic method based on Randox reagents was used to determine the content of beta-hydroxybutyric acid (BHBA) and free fatty acids (NEFA) in the blood plasma. In the urine, $\mathrm{pH}$ was determined immediately after sampling with the use of a pH-METER CP-551 microcomputer. Indicator strips were used to identify ketone bodies, glucose, protein, urobilinogen, and blood. Moreover, in the laboratory, glucose and beta-hydroxybutyric acid were determined in the urine samples with Cormay and Randox monotests.

The experiments were approved by the $2^{\text {nd }}$ Local Ethics Committee for Animal Testing in Lublin (Resolution No. 35/2006 of 26 September 2006).

Statistical analyses. The parameter indices and metabolic rate were analyzed statistically with Statistica ver. 5.1.G. (StatSoft, Inc.) by analysis of variance according to the model:

$Y_{i j k}=\mu+a_{i}+b_{j}+c_{k}+(a b)_{i j}+(a c)_{i k}+(b c)_{j k}+(a b c)_{i j k}+e_{i j k}$ where: $\mu$-overall mean; $a_{i}$ - effect of $i$-additive; $b_{j}$ - effect of $j$-physiological period; $c_{k}$ - effect of $k$-date; $(a b)_{i j}^{j}$ - effect of $i$-additive and $j$-physiological period interaction; $(a c)_{i k}$ - effect of $i$-additive and $k$-date interaction; $(b c)_{j k}$ - effect of $j$-physiological period and $k$-date interaction; $(a b c)_{i j k}$ - effect of $i$-additive, $j$-physiological period and $k$-date; $e_{i j k}$-random error.

The significance of differences between the means was determined with Duncan's multiple confidence interval set at 0.05 and 0.01 levels of significance.

\section{Results and discussion}

Three weeks before parturition, the body condition scores of the cows amounted on average to $3.80 \mathrm{BCS}$ (Tab. 3), whereas after calving, they decreased in the $2^{\text {nd }}$ and $14^{\text {th }}$ weeks, compared to the prepartum. The lowest loss of condition scores $(p \leq 0.05)$ in the first two weeks and in the $14^{\text {th }}$ week postpartum was noted the G1 group of cows (Tab. 3), whose diet was supplemented with the glucogenic preparation until the $3^{\text {rd }}$ lactation week. A comparison of the cows' condition scores in the $14^{\text {th }}$ week of lactation with their scores in the $2^{\text {nd }}$ week after calving indicates a markedly lower loss in the cows receiving the experimental additives (Tab. 3 ). 
Tab. 3. Body condition score of cows during the trial

\begin{tabular}{|c|c|c|c|c|c|c|c|}
\hline \multirow[t]{2}{*}{ Group } & \multicolumn{7}{|c|}{$\begin{array}{l}\text { Body condition, BCS } \\
\text { Observation week (calving day }=0 \text { ) }\end{array}$} \\
\hline & & -3 & & & +2 & & +14 \\
\hline $\begin{array}{l}\text { C } \\
\text { G1 } \\
\text { G2 } \\
\text { F1 } \\
\text { F2 }\end{array}$ & & $\begin{array}{l}3.78 \\
3.80 \\
3.82 \\
3.80 \\
3.76\end{array}$ & & & $\begin{array}{l}3.21^{\mathrm{b}} \\
3.38^{\mathrm{a}} \\
3.36^{\mathrm{a}} \\
3.30^{\mathrm{b}} \\
3.28^{\mathrm{b}}\end{array}$ & & $\begin{array}{l}2.98^{\mathrm{b}} \\
3.35^{\mathrm{a}} \\
3.30^{\mathrm{a}} \\
3.21^{\mathrm{a}} \\
3.25^{\mathrm{a}}\end{array}$ \\
\hline SEM & & 0.28 & & & 0.47 & & 0.85 \\
\hline \multirow[t]{2}{*}{ Parameter } & & & & & Effect o & & interaction of factors \\
\hline & A & $\mathbf{P}$ & W & $A \times P$ & $A \times W$ & $P \times W$ & $A \times P \times W$ \\
\hline Body condition (BCS) & * & * & * & ns & ns & * & ns \\
\hline
\end{tabular}

Explanations: ${ }^{a, b}-$ values differ significantly between groups at $\mathrm{p}<0.05$; ${ }^{1}$ probability of factor impact $(\mathrm{A}=$ additive: $\mathrm{G}$ or $\mathrm{F}), \mathrm{P}=$ physiological period, $\mathrm{W}=$ week) and interaction of factors: $* \mathrm{p} \leq 0.05, * * \mathrm{p} \leq 0.01$

Tab. 4. Daily yield per 100 days of lactation

\begin{tabular}{|l|c|c|c|c|c|}
\hline Group & $\begin{array}{c}\text { Milk yield } \\
{[\mathrm{kg} / \text { day] }}\end{array}$ & Fat [\%] & SNF [\%] & $\begin{array}{c}\text { Energy } \\
{[\text { Mcal/kg] }}\end{array}$ & $\begin{array}{c}\text { Energy yield } \\
{[\text { Mcal] }}\end{array}$ \\
\hline C & $31.28^{\mathrm{b}}$ & $3.86^{\mathrm{b}}$ & $8.38^{\mathrm{b}}$ & $0.71^{\mathrm{b}}$ & $22.25^{\mathrm{c}}$ \\
G1 & $34.26^{\mathrm{a}}$ & $3.83^{\mathrm{b}}$ & $8.19^{\mathrm{b}}$ & $0.70^{\mathrm{b}}$ & $23.96^{\mathrm{ab}}$ \\
G2 & $35.05^{\mathrm{a}}$ & $3.91^{\mathrm{ab}}$ & $7.99^{\mathrm{b}}$ & $0.70^{\mathrm{b}}$ & $24.43^{\mathrm{a}}$ \\
F1 & $30.88^{\mathrm{b}}$ & $4.10^{\mathrm{a}}$ & $8.84^{\mathrm{a}}$ & $0.76^{\mathrm{a}}$ & $23.35^{\mathrm{b}}$ \\
F2 & $31.88^{\mathrm{b}}$ & $4.02^{\mathrm{ab}}$ & $8.56^{\mathrm{a}}$ & $0.74^{\mathrm{a}}$ & $23.43^{\mathrm{b}}$ \\
SEM & 0.836 & 0.115 & 0.147 & 0.012 & 0.365 \\
\hline
\end{tabular}

Explanations: a, b, c - values differ significantly between groups at $\mathrm{p}<0.05$

A positive effect of the feed additives on the cows' milk performance and milk composition, calculated per 100 days of lactation, was observed (Tab. 4). In the present study, irrespectively of the supplementation duration, a significantly $(\mathrm{p} \leq 0.05)$ higher milk production was noted in the glucogenic preparationsupplemented cows (groups G1 and G2). On the other hand, in the F1 and F2 groups a significantly $(\mathrm{p} \leq 0.05)$ higher content of basic compounds and energy was found. In all experimental groups, a significantly increased energy yield was noted as compared with the control group. However, a comparison of the two energy additives ( $G$ vs. F) showed a higher energy yield per 100 days of lactation in the groups receiving propylene glycol and Na-propionate, with the highest energy efficiency in the $\mathrm{G} 2$ group.

There was a positive relationship between the duration of glucogenic additive application and milk production at the peak of lactation $\left(10^{\text {th }}\right.$ week post parturition) and a negative relationship between its duration and the milk fat content. In the cows supplemented with the free fatty acid preparation, however, an inverse relationships were revealed (data not shown).

In this study (Tab. 5), the experimental factors had an evident effect on glucose (GLU), beta-hydroxybutyric acid (BHBA), and non-esterified fatty acids (NEFA). The glucose fraction in the blood plasma during lactation was significantly higher in the cows receiving the glucogenic preparation (groups G1 and G2). Furthermore, the average content of BHBA in the cows from the control group (C) over the entire 14-week post-calving period was significantly higher compared to its content in the blood plasma drawn from the other groups. The highest concentration of this acid was recorded in the cows from the control group from the $4^{\text {th }}$ week of lactation until the end of the experiment $\left(14^{\text {th }}\right.$ week of milking). An analogous relationship was observed for free fatty acids in blood plasma. All experimental factors significantly $(\mathrm{p} \leq 0.01)$ affected BHBA and NEFA levels (Tab. 5). Also the interaction of the factors $(\mathrm{A} \times \mathrm{P} ; \mathrm{A} \times \mathrm{W}$; $\mathrm{A} \times \mathrm{P} \times \mathrm{W})$ had a significant $(\mathrm{p} \leq 0.05)$ impact on both indices. Glucose concentration, on the other hand, depended $(p \leq 0.05)$ only on the type of energy additive (A).

The supplements also contributed to the increased total cholesterol content in the blood plasma of cows (Tab. 5), confirmed statistically $(\mathrm{p} \leq 0.05)$ from the $6^{\text {th }}$ week of lactation onwards. A gradual increase in the level of this indicator was observed over the lactation period. Similarly, the concentration of HDL-Chol in the blood plasma of the cows fed with the supplements was significantly higher from the $6^{\text {th }}$ week of lactation onwards, in comparison with the control group. However, the effect of the supplements used on the content of triacylglycerols in blood plasma was equivocal and statistically insignificant. A statistically significant $(p \leq 0.05)$ impact of the type of additive, physiological period, and week of lactation on total cholesterol and its fraction levels was found. Interaction between the experimental factors did not influence lipid indices.

Cow urine tests performed with the use of testing strips three weeks before and two weeks after calving revealed the presence of ketone bodies, while glucose, protein, and urobilinogen were also identified in individual cows (data not shown). However, in the subsequent weeks of lactation, traces of ketone bodies were found only in the urine of the control group (C). No significant effect of the supplements on the acidity of urine was identified: only the animals from the control group showed a short-term reduction in $\mathrm{pH}$ values 2 weeks after calving (Tab. 6). In quantity tests, glucose and beta-hydroxybutyric acid were found in the urine of all cows, but the glucose content was lower for the cows receiving the experimental supplements than it was for the control group. Furthermore, there were significant $(p \leq 0.05)$ changes in the content of glucose depending on the date of urine analysis and the physiological period of cows. In particular, two weeks after calving, cows selected from the control group had increased levels of BHBA in their urine. 
Tab. 5. Blood plasma biochemical parameters of pregnant and lactating cows [mmol $\left.\mathrm{m}^{-1}\right]$

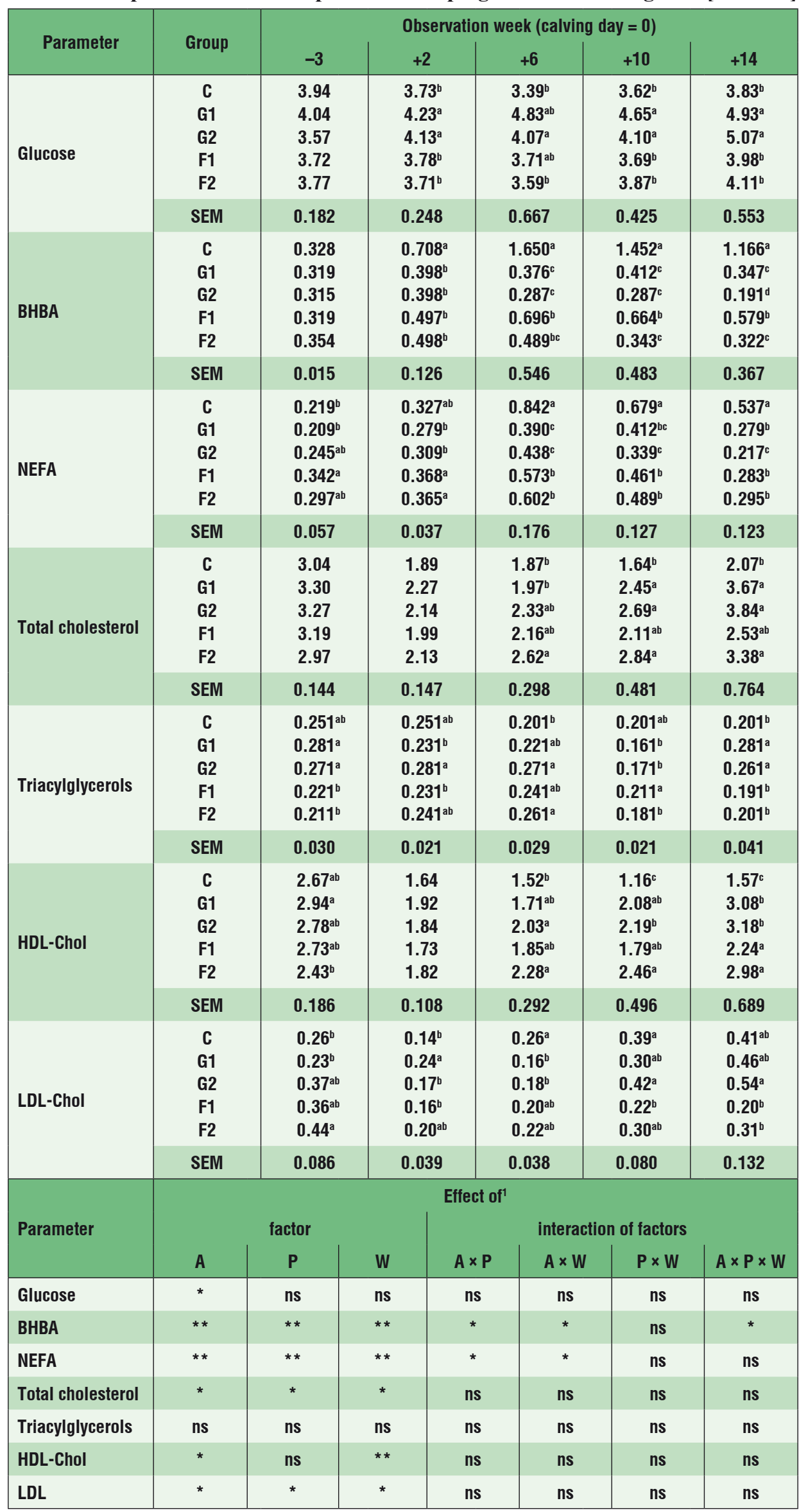

Explanations: $\mathrm{a}, \mathrm{b}$ - values differ significantly between groups at $\mathrm{p} \leq 0.05$; ${ }^{1}$ probability of factor impact ( $\mathrm{A}=$ additive: $\mathrm{G}$ or $\mathrm{F}, \mathrm{P}=$ physiological period, $\mathrm{W}=$ week) and interaction of factors: $* \mathrm{p} \leq 0.05, * * \mathrm{p} \leq 0.01, \mathrm{~ns}=\mathrm{p}>0.05$
The significantly lowest content of beta-hydroxybutyric acid in urine was a characteristic of the cows receiving the glucogenic supplement until the $6^{\text {th }}$ week of lactation (group G2). This effect fully corresponded to the total content of ketone bodies revealed by the strip test of urine.

In the transition period, cows with high genetic potential are most susceptible to energy deficiency associated with loss of appetite (32). This results, at best, in a decreased milk production and changes in milk composition. However, metabolic disorders and even involuntary culling of cows may also occur. Nutritional energy deficiencies in cows in early lactation can largely be prevented by well-balanced feed rations and gluconeogenic supplementation (3). Therefore, the type of feed additives is critically important. Feed additives not only supply sufficient energy, but also affect the general health status of animals and modify the composition of their milk (22). In the present study, the intake of the basal diets provided to all experimental groups was at a similar level (data not shown). However, from the $2^{\text {nd }}$ week of lactation onwards, especially in the $6^{\text {th }}$ week, a higher dry matter intake was noted, particularly in the glucogenic preparationsupplemented groups, compared to the control treatments (27). This may have resulted from the high digestibility of the additive, an increased intensity of digestive processes, or the individual predisposition of the animals (5).

In the $3^{\text {rd }}$ week before calving, there were minor differences in the cows' body conditions, and only some animals had developed excess adiposity. Cows with too much fatty deposit may drastically reduce feed intake immediately before parturition. This, in turn, results in lower feed intakes and greater weight loss after calving. This situation often persists through the first weeks 
Tab. 6. Biochemical parameters in the urine of cows

\begin{tabular}{|c|c|c|c|c|c|c|c|}
\hline \multirow{2}{*}{ Parameter } & \multirow{2}{*}{ Group } & \multicolumn{6}{|c|}{ Observation week (calving day = 0 ) } \\
\hline & & -3 & & +2 & +6 & +10 & +14 \\
\hline \multirow[t]{2}{*}{ pH } & $\begin{array}{l}\text { C } \\
\text { G1 } \\
\text { G2 } \\
\text { F1 } \\
\text { F2 }\end{array}$ & $\begin{array}{l}8.42 \\
9.04 \\
8.79 \\
8.96 \\
8.92\end{array}$ & & $\begin{array}{l}7.94^{\mathrm{b}} \\
8.47^{\mathrm{ab}} \\
9.03^{\mathrm{a}} \\
8.62^{\mathrm{a}} \\
8.63^{\mathrm{a}}\end{array}$ & $\begin{array}{l}8.02^{\mathrm{b}} \\
9.32^{\mathrm{a}} \\
9.31^{\mathrm{a}} \\
8.70^{\mathrm{ab}} \\
8.91^{\mathrm{ab}}\end{array}$ & $\begin{array}{l}8.53^{b} \\
8.86^{b} \\
9.35^{a} \\
8.81^{b} \\
9.02^{a b}\end{array}$ & $\begin{array}{l}8.68 \\
9.11 \\
8.90 \\
8.94 \\
8.97\end{array}$ \\
\hline & SEM & 0.244 & & 0.394 & 0.536 & 0.301 & 0.156 \\
\hline \multirow[t]{2}{*}{ Glucose [mmol l-1] } & $\begin{array}{l}\text { C } \\
\text { G1 } \\
\text { G2 } \\
\text { F1 } \\
\text { F2 }\end{array}$ & $\begin{array}{l}2.55^{\mathrm{a}} \\
2.23^{\mathrm{a}} \\
2.31^{\mathrm{a}} \\
1.94^{\mathrm{b}} \\
1.83^{\mathrm{b}}\end{array}$ & & $\begin{array}{l}2.94^{\mathrm{a}} \\
2.34^{\mathrm{ab}} \\
2.2 \mathrm{~g}^{\mathrm{ab}} \\
1.77^{\mathrm{b}} \\
2.08^{\mathrm{ab}}\end{array}$ & $\begin{array}{l}3.07^{\mathrm{a}} \\
2.45^{\mathrm{ab}} \\
2.09^{\mathrm{b}} \\
1.96^{\mathrm{b}} \\
1.54^{\mathrm{b}}\end{array}$ & $\begin{array}{l}3.12^{\mathrm{a}} \\
2.20^{\mathrm{b}} \\
1.99^{\mathrm{b}} \\
1.80^{\mathrm{c}} \\
1.20^{\mathrm{c}}\end{array}$ & $\begin{array}{l}1.32^{\mathrm{a}} \\
1.06^{\mathrm{a}} \\
0.83^{\mathrm{b}} \\
0.73^{\mathrm{b}} \\
0.50^{\mathrm{b}}\end{array}$ \\
\hline & SEM & 0.290 & & 0.430 & 0.575 & 0.699 & 0.314 \\
\hline \multirow[t]{2}{*}{ BHBA [mmol l-1] } & $\begin{array}{l}\text { C } \\
\text { G1 } \\
\text { G2 } \\
\text { F1 } \\
\text { F2 }\end{array}$ & $\begin{array}{l}1.52^{\mathrm{a}} \\
0.78^{\mathrm{b}} \\
0.92^{\mathrm{b}} \\
0.81^{\mathrm{b}} \\
0.96^{\mathrm{b}}\end{array}$ & & $\begin{array}{l}1.64^{\mathrm{a}} \\
0.53^{\mathrm{b}} \\
0.51^{\mathrm{b}} \\
0.91^{\mathrm{ab}} \\
0.89^{\mathrm{ab}}\end{array}$ & $\begin{array}{l}2.56^{\mathrm{a}} \\
0.63^{\mathrm{c}} \\
0.42^{\mathrm{c}} \\
1.17^{\mathrm{b}} \\
0.77^{\mathrm{bc}}\end{array}$ & $\begin{array}{l}1.62^{\mathrm{a}} \\
0.51^{\mathrm{b}} \\
0.38^{\mathrm{b}} \\
0.99^{\mathrm{ab}} \\
0.78^{\mathrm{b}}\end{array}$ & $\begin{array}{l}0.97^{\mathrm{a}} \\
0.38^{\mathrm{b}} \\
0.30^{\mathrm{b}} \\
0.93^{\mathrm{a}} \\
0.73^{\mathrm{ab}}\end{array}$ \\
\hline & SEM & 0.301 & & 0.457 & 0.856 & 0.488 & 0.309 \\
\hline \multirow[t]{2}{*}{ Parameter } & \multicolumn{3}{|c|}{ factor } & Effe & interac & of factors & \\
\hline & A & $\mathbf{P}$ & W & $A \times$ & $A \times W$ & $P \times W$ & $A \times P \times W$ \\
\hline pH & ns & ns & ns & ns & ns & ns & ns \\
\hline Glucose & ** & ** & ** & * & ns & * & ns \\
\hline BHBA & ** & ns & ** & * & ns & ns & ns \\
\hline
\end{tabular}

Explanations: $\mathrm{a}, \mathrm{b}$ - values differ significantly between groups at $\mathrm{p} \leq 0.05$; ${ }^{1}$ probability of factor impact $(\mathrm{A}=$ additive: $\mathrm{G}$ or $\mathrm{F}, \mathrm{P}=$ physiological period, $\mathrm{W}=$ week $)$ and interaction of factors: $* \mathrm{p} \leq 0.05, * * \mathrm{p} \leq 0.01, \mathrm{~ns}=\mathrm{p}>0.05$

postpartum and leads to an excessive negative energy balance in the organism $(22,37)$. In our experiment, the cows from the control group showed significant loss of condition from the $3^{\text {rd }}$ week before parturition until the $14^{\text {th }}$ week after parturition. In cows from the experimental groups receiving the experimental additives, the loss of condition was much lower. This demonstrates an optimal concentration of energy supplied in relation to the animals' requirements. Furthermore, the supplements contributed to the increased milk performance of cows in the experimental groups, which was on average by ca. $8 \%$ better than that of the control cows. Furthermore, the average daily milk yield of the cows provided with the glucogenic preparation in their diet was higher by as much as $13 \%$ than in the control. This result indicates an appropriate energy level in their feed ration as well as its optimal availability at the level of the rumen and small intestine. The free fatty acid preparation additive also improved the efficiency of cow milk production, but only by ca. $3 \%$.

The analysis of blood components is a useful tool in evaluating the health or nutrition status of a cow $(1,10)$, especially with regard to the level of energy supplied $(16,38)$. Three fundamental blood parameters are needed to evaluate the energy nutrition status of a cow: glucose, beta-hydroxybutyric acid (BHBA), and non-esterified fatty acids (NEFA) (16). It must be noted that the content of glucose in blood is not very stable. Its level changes during the day and night, differs in stressful situations, and increases after feeding. While the level of glucose in the organism is strictly controlled by insulin and other hormones (44), it is generally believed that the content of glucose in blood plasma reflects its current level in the organism. In this study, the mean content of glucose in blood plasma fell within reference limits (52), yet the energy supplements contributed to an increase in the content of glucose in blood plasma (28). This effect during the experiments was a reflection of the animals physiological condition, but was not explicit.

Compared with the control group, the cows receiving the experimental supplements also had a significantly reduced concentration of beta-hydroxybutyric acid and NEFA in their blood plasma. It is believed that the content of BHBA in blood is an indicator of the short-term energy status of the organism $(16,44,45)$. Hence, the evaluation of the content of this acid in blood plasma can be used to diagnose subclinical ketosis, whereas the content of non-esterified fatty acids (NEFA) in the blood plasma indicates the status of energy processes over a longer period. Thus, an increased level of these acids reflects the size of fat reserves mobilized in the organism $(6,44)$. An increase in the concentration of NEFA is a response to an insufficient intake of energy with the ration in relation to the need $(25,26)$. Chung et al. (6) and Janovick et al. (19) suggest that the concentration of NEFA in cows should be below $0.7 \mathrm{mmol}^{-1}$ at early stages of lactation, and below $0.4 \mathrm{mmol} \mathrm{l}^{-1}$ at the final stage of pregnancy. A high level of BHBA and/or a high concentration of NEFA, given normal or low contents of glucose in cows' blood plasma, may constitute evidence of an existing energy deficiency, but this condition does not necessarily mean that the feed ration is deficient in energy (22). The addition of feed fat can increase the content of NEFA in blood plasma. However, Moallem et al. (36) found that the average increase in the NEFA concentration in blood plasma after the introduction of a fat supplement was definitely lower than changes in the content of NEFA typical of the transition period. McArt et al. (33) claim that a feed fat supplement can decrease the mobilization of energy reserves, and thus the concentration of 
NEFA in blood plasma, and reduce the probability of ketosis. Opinions are split (40).

Because determination of ketone compounds in blood is a complex process, in practice it is enough to identify these compounds in urine by means of quality test strips. With regard to acidity, when evaluating the $\mathrm{pH}$ of urine in ruminants, the type of feeds administered to the animals should be taken into account (52).

It should be noted that the urine of healthy animals should not contain glucose (52). The experiments carried out revealed that small amounts of this sugar were present in the animal urine tested, and the highest mean concentrations were found in the urine of the cows two and six weeks after calving. However, the interpretation of such results must take into account physiological glycosuria. This condition can occur as a consequence of pregnancy, stress, enhanced rations of feeds rich in easily digested carbohydrates, and lactation (52). In our experiment, the supplements used, in particular the glucogenic supplement (a precursor of glucose), significantly reduced the level of glucose in urine. Although the glucose content in the urine of the experimental cows increased slightly during the initial weeks of lactation (which could have been an immediate consequence of providing energy supplements with feed rations), it gradually decreased in the subsequent weeks. This may constitute evidence of the optimum balance (between supply and use) of energy in feed rations for cows in that period. The supplements, which were an additional source of energy for the cow's organism, played a role in the optimum use of energy.

With regard to ketone compounds, only trace amounts are allowed in the urine of healthy animals $(13,52)$, and an increased concentration of these compounds in ruminants is a symptom of ketosis, liver failure, acidosis, or starvation (34). Beta-hydroxybutyric acid is a predominant ketone compound in urine (52). The highest concentration of these compounds in urine was recorded in the control group, while the lowest was determined in the cows receiving the glucogenic supplement or the fatty acid preparation.

Changes in the values of lipid parameters of blood: total cholesterol, its high-density lipoprotein (HDL) and low-density lipoprotein (LDL) particles, and triacylglycerols (TG), are significant in evaluating the course of metabolic processes in the organism. The supplements used in our experiments contributed to an increase in the concentration of total cholesterol in the blood plasma of the experimental cows. This situation should be regarded as favorable, since in ruminants, unlike in humans, a reduced concentration of cholesterol may be a problem $(43,46)$. We found that, regardless of the type of supplement used, there was a positive relationship between the duration of application and the content of total cholesterol in blood plasma. In addition, the concentration of HDL-Chol (\%) in the blood plasma of cows receiving energy supplements was significantly higher than in the control group.
Additionally, the supplements had influence on the content of triacylglycerols (TG) in the blood plasma of cows. TGs are the main form in which fat reserves are stored in the body, and these are accumulated in adipose cells and released into the bloodstream when needed (21). Lactation is a period during which the greatest amounts of triacylglycerols are released from adipose cells. This opinion is supported by our studies.

The content of major milk constituents (mainly lactose and protein) is mainly conditioned genetically, and therefore the demand for the precursors of these components (glucose, propionic acid) increases along with a growing cow milk yield. A deficiency of glucose sources in early lactation has primarily a negative impact on the milk protein level, as the lack of energy sources is responsible for the use of amino acids for glucose synthesis, rather than for lactose formation (8). Substantial amounts of fiber in a feed ration are conducive to an increased acetic acid level in the rumen (precursor of milk fat), and this effect occurs at the expense of propionic and butyric acid levels. Further, low milk fat is reported for an increased concentrated feed content in a feed ration at the expense of roughages, which takes place when the level of the precursor of milk fat, i.e. acetic acid, declines in the rumen. In the present research, the protein and fat content in milk varied depending on the collection date. It may be concluded that the energy supplements helped maintain the protein and fat content at the optimal level. The best results were obtained for the cows fed the glucogenic additive at an amount of $500 \mathrm{~g} / \mathrm{head} /$ day until the end of the $6^{\text {th }}$ week of lactation. Moreover, this group of cows (G2) had the highest milk yield assessed for 305 days of lactation.

The present research confirmed the benefits of dietary inclusion of energy supplements for transition cows. Supplementation with both glucogenic and free fatty acid preparations reduced the negative energy balance in the cow's organism and improved milk production and composition. Furthermore, factors such as the ration and supplement type as well as their administration period have been found to limit negative impact on body condition in periparturient cows. The milk yield, higher by ca. $10 \%$ for the cows fed diets with energy additives (relative to the control treatment), provide evidence of a substantial beneficial effect of supplemental dietary energy on the efficiency of cow milk production.

In the present study, the best basic milk composition was obtained in the cows receiving a dietary addition of the glucogenic preparation at a dose of $500 \mathrm{~g} / \mathrm{head} /$ day until the end of the $6^{\text {th }}$ lactation week. The animals from this group also had the highest milk yield evaluated for 305 days. In order to improve the energy balance in high-yielding transition cows, it is recommended that dairy managers apply feed energy additives based on propylene glycol and sodium propionate. 


\section{References}

1. Ahmad I., Gohar A., Ahmad N., Ahmad M.: Haematological profile in cyclic, non cyclic and endometritic cross-bred cattle. Int. J. Agric. Biology 2003, 05, 332-334

2. AOAC. Official Methods of Analysis International. $18^{\text {th }}$ Ed. Gaithersburg, MD, USA 2007.

3. Bors S. I., Solcan G., Vlad-Sabie A.: Effects of propylene glycol supplementation on blood indicators of hepatic function, body condition score, milk fat-protein concentration and reproductive performance of dairy cows. Acta Vet. Brno 2014 , $83,27-32$

4. Brzozowska A. M., Oprzadek J.: Metabolism of fatty acids in tissues and organs of the ruminants-a review. Anim. Sci. Pap. Rep. 2016, 34, 211-220.

5. Chamberlain A. T., Wilkinson J. M.: Feeding the Dairy Cow. Chalcombe Publication. Lincoln, UK 2002.

6. Chung Y.-H., Brown N. E., Martinez C. M., Cassidy T. W., Varga G. A.: Effects of rumen-protected choline and dry propylene glycol on feed intake and blood parameters for Holstein dairy cows in early lactation. J. Dairy Sci. 2009, 92 , 2729-2736.

7. Cieślak A., El-Sherbiny M., Szczechowiak J., Kowalczyk D., Pers-Kamczyc E. Bryszak M., Szulc P., Jóźwik A., Szumacher-Strabel M.: Rapeseed and fish oil mixtures supplied at low dose can modulate milk fatty acid composition without affecting rumen fermentation and productive parameters in dairy cows. Anim. Sci. Pap. Rep. 2015, 33, 357-372.

8. Dewhurst R. J.: Milk production from silage: comparison of grass, legume and maize silage and their mixture. Agric. Food Sci. 2013, 22, 57-69.

9. Douglas G. N., Rehage J., Beaulieu A. D., Bahaa A. O., Drackley J. K.: Prepartum nutrition alters fatty acid composition in plasma, adipose tissue, and liver lipids of periparturient dairy cows. J. Dairy Sci. 2007, 90, 2941-2959.

10. French P. D.: Dry matter intake and blood parameters of nonlactating Holstein and Jersey cows in late gestation. J. Dairy Sci. 2006, 89, 1057-1061.

11. Friedewald W. T., Levy R. I., Fredrickson D. S.: Estimation of the plasma lowdensity lipoprotein cholesterol without use of the preparative ultracentrifuge. Clin. Chem. 1972, 18, 499-502.

12. Gonthier C., Mustafa A. F., Oullet D. R., Chouinard P. Y., Bertianne R., Petit $H$. $V$ : Feeding micronized and extruded flaxseed to dairy cows: effects on blood parameters and milk fatty acid composition. J. Dairy Sci. 2005, 88, 748-756.

13. Guo J., Peters R. P., Kohn R. A.: Modeling nutrient fluxes and plasma keton bodies in periparturient cows. J. Dairy Sci. 2008, 91, 4282-4292.

14. Harmon D. L.: Impact of nutrition on pancreatic exocrine and endocrine secretion in ruminants: a review. J. Anim. Sci. 1992, 70, 1290-1301.

15. Hayirli A., Keisler D. H., Doepel L.: Peripartum responses of dairy cows to prepartal feeding level and dietary fatty acid source. J. Dairy Sci. 2011, 94, 917-930

16. Herdt T. H., Rumbeina W., Braselton W. E.: The use of blood analyses to evaluate mineral status in livestock. Vet. Clin. North Am.: Food Anim. Pract. 2000, 16, 423-444.

17. Hippen A. R., De Frain J. M., Linke P. L.: Glycerol and other energy sources for metabolism and production of transition dairy cows, [in:] Proc. $19^{\text {th }}$ Annual Florida Ruminant Nutrition Symposium, Gainesville, FL 2008.

18. IZ PIB-INRA: Feeding of cattle, sheep and goats. Feeding value of feedstuffs for ruminants. National Research Institute of Animal Production, Krakow, Poland (in Polish) 2009

19. Janovick N. A., Boisclair Y. R., Drackley J. K.: Prepartum dietary energy intake affects metabolism and health during the periparturient period in primiparous and multiparous Holstein cows. J. Dairy Sci. 2011, 94, 1358-1400.

20. Karcagi R. G., Gaal T., Ribiczey P., Huszenicza G., Husveth F.: Milk production, peripartal liver triacylglycerol concentration and plasma metabolites of dairy cows fed diets supplemented with calcium soaps or hydrogenated triacylglycerols of palm oil. J. Dairy Res. 2010, 77, 151-158

21. Kessler E. C., Gross J. J., Bruckmaier R. M., Albrecht C.: Cholesterol metabolism, transport, and hepatic regulation in dairy cows during transition and early lactation. J. Dairy Sci. 2014, 97, 5481-5490.

22. Klebaniuk R.: Effectiveness of glucogenic preparation in the diets containing grains with different ruminal starch degradation in high yielding dairy cows (in Polish). Praca hab. Wydział Biologii i Hodowli Zwierząt UP, Lublin 2008.

23. Klebaniuk R., Kowalczuk-Vasilev E., Rocki G., Matras J., Olcha M., Bąkowski M. Effect of glucogenic additive in transition dairy cow diets of varying ruminal starch degradability on blood metabolic profile. Annales UMCS 2015, 33, 71-81.

24. Klebaniuk R., Matras J., Kowalczuk-Vasilev E.: Blood metabolic profile parameters of cows fed diet with glucogenic additive. Med. Weter. 2009, 65, 765-770.

25. Knegsel A. T. M. van, Brand H., Dijkstra J., Straalen W. M., Heetkamp M. J. W., Tamminga $S$., Kemp B.: Dietary energy source in dairy cows in early lactation: energy partitioning and milk composition. J. Dairy Sci. 2007a, 90, 1467-1476.

26. Knegsel A. T. M. van, Brand H., Dijkstra J., Straalen W. M., Jorritsma R., Tamminga S., Kemp B.: Effect of glucogenic vs. lipogenic diets on energy balance, blood metabolites, and reproduction in primiparous and multiparous dairy cows in early lactation. J. Dairy Sci. 2007b, 90, 3397-3409.

27. Kochman G.: Wpływ preparatów energetycznych na wydajność, skład mleka oraz wybrane wskaźniki krwi krów. Influence of high-energy preparations on yield, composition of milk and some blood indices of cows. Praca dokt. Wydział Biologii i Hodowli Zwierząt UP, Lublin 2012

28. Kristensen N. B., Raun B. M. L.: Ruminal and intermediary metabolism of propylene glycol in lactating Holstein cows. J. Dairy Sci. 2007, 90, 4707-4717.

29. Kuhla B., Metges C. C., Hammon H. M.: Endogenous and dietary lipids influencing feed intake and energy metabolism of periparturient dairy cows. Domest Anim. Endocrinol. 2016, 56, S2-S10.

30. Liu Q., Wang C., Yang W. Z., Guo G., Yang X. M., He D. C., Dong K. H., Huang $Y . X$.: Effects of calcium propionate supplementation on lactation performance, energy balance and blood metabolites in early lactation dairy cows. J. Anim. Physiol. Anim. Nutr. 2010, 94, 605-614.

31. Loften J. R., Linn J. G., Drackley J. K., Jenkins T. C., Soderholm C. G., Kertz A. F.: Palmitic and stearic acid metabolism in lactating dairy cows. J. Dairy Sci. 2014, 97, 1-14.

32. Matras J., Klebaniuk R., Kowalczuk-Vasilev E.: Impact of glucogenic additive in dairy cow diets based on grains of varied ruminal starch degradation on yield and composition of milk and reproductive parameters. Czech J. Anim. Sci. 2012, 57, 301-311.

33. McArt J. A. A., Nydam D. V., Oetzel G. R.: A field trial on the effect of propylene glycol on displaced abomasums, removal from herd, and reproduction in fresh cows diagnosed with a subclinical ketosis. J. Dairy Sci. 2012, 95, 2505-2512.

34. McArt J. A. A., Nydam D. V., Oetzel G. R., Overton T. R., Ospina P. A.: Elevated non-esterified fatty acids and $\beta$-hydroxybutyrate and their association with transition dairy cow performance. Vet. J. 2013, 198, 560-570.

35. Miyoshi S., Pate J. L., Palmquist D. L.: Effects of propylene glycol drenching on energy balance, plasma glucose, plasma insulin, ovarian function and conception in dairy cows. Anim. Reprod. Sci. 2001, 68, 29-43.

36. Moallem U., Katz M., Arieli A., Lehrer H.: Effects of peripartum propylene glycol or fats differing in fatty acid profiles on feed intake, production, and plasma metabolites in dairy cows. J. Dairy Sci. 2007, 90, 3846-3856.

37. Mustafa A.: Body condition score. Dairy Cattle Production. Department of Anim. Sci. McGill Faculty of Agricultural and Environment Sci. 2003, 342-450A, 1-9.

38. Nielsen N. I., Ingvartsen K. L.: Propylene glycol for dairy cows: a review of the metabolism of propylene glycol and its effects on physiological parameters, feed intake, milk production and risk of ketosis. Anim. Feed Sci. Technol. 2004, 115, 191-213.

39. Oba M., Allen M. S.: Effects of intraruminal infusion of sodium, potassium, and ammonium on hypophagia from propionate in lactating dairy cows. J. Dairy Sci. 2003, 86, 1398-1404

40. Osman M. A., Allen P. S., Bobe G., Coetzee J. F., Abuzaid A., Koehler K., Beitz $D$. C.: Chronic metabolic responses of postpartal dairy cows to subcutaneous glucagon injections, oral glycerol, or both. J. Dairy Sci. 2010, 93, 3505-3512.

41. Palmquist D. L., Jenkins T. C.: Fat in lactation rations: review. J. Dairy Sci. 1980, 63, 1-14.

42. Petit H. V., Germiquet C., Lebel D.: Effect of feeding whole unprocessed sunflower seeds and flaxseed on milk production, milk composition, and prostaglandin secretion in dairy cows. J. Dairy Sci. 2004, 87, 3889-3898.

43. Puppel K., Kuszyńska B.: Metabolic profiles of cow's blood; a review. J. Sci. Food Agric. 2016, 96, 4321-4328.

44. Reader J.: Blood profiling bonus. Dairy Farmer. Nutrition 2003, 3, 70-72.

45. Rizos D., Kenny D. A., Griffin W., Quinn K. M., Duffy P., Mulligan F. J., Roche J. F., Boland M. P., Lonergan P.: The effect of feeding propylene glycol to dairy cows during the early postpartum period on follicular dynamics and metabolic parameters related to fertility. Theriogenology 2008, 69, 688-699.

46. Schlegel G., Ringseis R., Keller J., Schwarz F. J., Eder K.: Changes in the expression of hepatic genes involved in cholesterol homeostasis in dairy cows in the transition period and at different stages of lactation. J. Dairy Sci. 2012, 95, 3826-3836

47. Soest Van P. J.: Nutritional Ecology of the Ruminant, Second Edition. Cornell University Press, Ithaca 1994

48. Szczechowiak J., Szumacher-Strabel M., El-Sherbiny M., Bryszak M., Stochmal A., Cieslak A.: Rumen fermentation, methane concentration and fatty acid proportion in the rumen and milk of dairy cows fed condensed tannin and/ or fish-soybean oils blend. Anim. Feed Sci. Technol. 2016, 216, 93-107.

49. Tyrrell H. F., Reid J. T.: Prediction of the energy value of cow's milk. J. Dairy Sci. $1965,48,1215-1223$

50. Vargas-Bello-Pérez E., Fehrmann-Cartes K., Íniguez-González G., ToroMujica P., Garnsworthy P. C.: Chemical composition, fatty acid composition, and sensory characteristics of Chanco cheese from dairy cows supplemented with soybean and hydrogenated vegetable oils. J. Dairy Sci. 2015, 98, 111-117.

51. White H. M., Carvalho E. R., Koser S. L., Schmelz-Roberts N. S., Pezzanite L. M., Slabaugh A. C., Doane P. H., Donkin S. S.: Short communication: Regulation of hepatic gluconeogenic enzymes by dietary glycerol in transition dairy cows. J. Dairy Sci. 2016, 99, 812-817.

52. Winnicka $A$.: Referential values of the substantial laboratory evaluations in veterinary practice (in Polish). SGGW, Warszawa 2015.

Corresponding author: dr hab. inż. Renata Klebaniuk, prof. nadzw. UP, Akademicka 13, 20-950 Lublin, Poland; e-mail: renata.klebaniuk@up.lublin.pl; klebaniuk@gmail.com 